\title{
Intellectual Capital, Firm Value, and Financial Performance
}

\author{
Aida Irsyahma ${ }^{*}$, Nikmah $^{2}$ \\ ${ }^{1,2}$ University of Bengkulu, Bengkulu, Indonesia
}

\begin{abstract}
The ownership of intangible assets especially intellectual capital has becoming more important in this modern era where technology and knowledge have significant roles in company operating activities. The objective of this study is to examine the effect of intellectual capital on firm value and financial performance as intervening variable. The sample in this study is the banking sector listed in Indonesia Stock Exchange between 2011-2014 and 15 banks become samples in this study. The data was analyzed using the path analysis method with SPSS.

The test result shows that intellectual capital has a positive effect on firm value, intellectual capital has a positive effect on financial performance, financial performance has a positive effect on firm value, and financial performance proved to intervene the relationship between intellectual capital and firm value.
\end{abstract}

\section{Keywords: Financial Performance, Firm Value, Intellectual Capital}

\section{INTRODUCTION}

The rapid development of science and technology in modern era has made companies realized that the ownership of intangible assets has a significant role just like tangible assets. One of the intangible assets is knowledge assets, such as ideas, information, creativity and company human resources' knowledge. Knowledge assets are better known as intellectual capital. The first known instance of intellectual capital is from Thomas Stewart's article which was released in 1991. After this article had been published, the research on intellectual capital began to be done especially to gives a precise definition of intellectual capital and to determine an appropriate indicator to measure intellectual capital. An example of this is the research that conducted by Pulic (2000).

According to Pulic (2000), intellectual capital is a part of knowledge that gives value added contribution to a company and will result in a competitive advantage. The most common indicators used by researchers to measure the performance of intellectual capital is VAICTM (Value Added Intellectual Coefficient).

Research on intellectual capital in Indonesia began after the publication of Statement of Financial Accounting Standard (PSAK) 19 which discussed intangible assets. In 2005, Dunamis Organization Services held Indonesian Most Admired Knowledge Enterprise (MAKE) Study. Indonesian MAKE Study is a study about the most self-sufficient company in the field of knowledge

* Corresponding author. Email address: aida.irsyahma@gmail.com 
management and intellectual capital in Indonesia. Data that was obtained from MAKE Study states that banking sector in Indonesia tend to report fewer intellectual capital attributes compared to companies in other sectors. In contrast, banking sector should receive the award every year since banking is an "intellectually intensive" business sector (Kamath, 2007), which means the quality of service to consumers rely heavily on the intelligence of human resources owned by the company. To that end, the utilization of intellectual capital should have been increased, especially in the banking sector.

Research conducted by Chen et al. (2005), Ulum (2007; 2008), and Clarke et al. (2011) investigate the relationship between intellectual capital and financial performance. The research proves a positive effect on financial performance and the results of research performed by Sunarsih (2012), Alghifari et al. (2013), and Sudibya (2014) showed that financial performance is positively related to firm value.

Another issue that also attracted the attention of academics and practitioners is the relationship between intellectual capital and firm value (Hong, 2007). Randa (2012), Berzkalne (2014) and Sudibya (2014) found that there is a positive relationship between intellectual capital and firm value. But, different results obtained from the research by Sunarsih (2012) and Muna (2014), which show that there is an indirect relationship between intellectual capital and firm value through financial performance.

The difference results between research by Sudibya (2014), Sunarsih (2012) and Muna (2014) became the underlying motivation for this research. The differences in results of previous studies may be caused by differences in the indicators used to calculate the performance of intellectual capital, the firm company, as well as the financial performance of companies that became the sample of their researches. This study aims to find the relationship between intellectual capital, financial performance and firm value to answer these question:

(1) Does intellectual capital has a positive effect on firm value.

(2) Does the intellectual capital has a positive effect on financial performance.

(3) Does the financial performance has a positive effect on firm value.

(4) Does the financial performance intervenes the relationship between intellectual capital and firm value.

This study uses M-VAIC model or VAICTM that have been modified to measure intellectual capital performance (Ulum, 2014), Return on Assets (ROA) for financial performance (Ulum, 2008) and Price to Book Value (PBV) for firm value (Sudibya, 2014).

\section{LITERATURE STUDY AND HYPOTHESES DEVELOPMENT Resources Based Theory (RBT)}

Resource-Based Theory was first presented by Wernerfelt (1984) I n his article. The article combines the idea by Selznick (1957) and Penrose (1959) concerning the definition of the enterprise as a system that produces resources (Ulum, 2013). However, the most influential article for intellectual capital research is an article by Barney (1991) which discussed about firm resources and sustained 
competitive advantage. RBT stated that a company has the resources to make a competitive advantage and able to manage itself to have an excellent long-term performance. A rare and valuable resources can be managed to create a competitive advantage so that the owned resources will be durable and can not be easily copied, transferred or substituted (Ulum, 2013).

RBT is a proper choice to describe research on intellectual capital, especially in the context of the relationship between intellectual capital, financial performance, and firm value. In intellectual capital's perspective, intangible assets of companies are classified into three main categories: human capital, structural capital, and customer capital (Bontis, 1998 in Ulum, 2013). According to Pulic (2004), each company has unique knowledge, skills, values and solutions -in this case, are intangible resources- that can be transformed into a 'value' in the capital market. Intangible resources that are efficiently managed can assist companies to achieve competitive advantage, increase productivity and its market value.

\section{Stakeholder Theory}

The stakeholder term in the classical definition is the definition by Freeman and Reed (1983) which states that the stakeholders are groups and individuals who can influence the achievement of company goals or those who are affected by the activities of the company during the company's pursuit of goals.

Based on stakeholder theory, organizational management is expected to perform activities that are important to their stakeholders and report those activities back to stakeholders. To explain the relationship of intellectual capital, financial performance, and firm value, stakeholder theory should be viewed from two fields, which are the ethics field and managerial field. Ethics field argues that all stakeholders have the right to be treated fairly by the organization, and managers should manage the organization for the benefit of all stakeholders (Deegan, 2004). Managerial fields of stakeholder theory views that the stakeholders ability to influence corporate management should be seen as a control over the resources needed by an organization (Watts and Zimmerman, 1986). Maximum management over the entire potential of the organization will give the opportunity to create value added that will increase the company's financial performance and increase the firm value in the capital market which is the purpose of stakeholders in influencing the company's management (Ulum, 2007).

\section{Intellectual Capital (IC)}

Intellectual capital is everything that can provide a competitive advantage for a company in the form of intangible resources such as knowledge, a technology used by the company, financial information as well as HR experiences that will result in the creation of value added for the company. According to Pulic (2004), intellectual capital consists of Human Capital (HC) and Structural Capital (SC). Human Capital represents the knowledge of an organization that is represented by its employees meanwhile SC covers the entire company's knowledge assets such as database, organizational charts, process manuals, strategies, routines and all the things that make the firm value's greater than the nominal value (Bontis et al. 2000 in Ulum, 2008). To measure the efficiency of intellectual capital, Pulic (2004) built a model called VAICTM consisting of Intellectual Capital Efficiency (ICE) and 
Capital Employed Efficiency (CEE) where ICE consisted of Human Capital Efficiency (HCE) and Structural Capital Efficiency (SCE).

The model used in this study is the M-VAIC, namely the VAICTM model by Pulic (2000) which has been modified by Ulum (2014) that adding the Relational Capital Efficiency (RCE) to be a part of the ICE to measure the performance of the company's intellectual capital with more comprehensively. RCE is a harmonious relationship between the company and its partners (Sawarjuwono and Kadir, 2003). HCE, SCE, and RCE will form ICE in M-VAIC model.The model used in this study is the M-VAIC, namely the VAICTM model by Pulic (2000) which has been modified by Ulum (2014) that adding the Relational Capital Efficiency (RCE) to be a part of the ICE in order to measure the performance of the company's intellectual capital with more comprehensively. RCE is a harmonious relationship between the company and its partners (Sawarjuwono and Kadir, 2003). HCE, SCE and RCE will form ICE in M-VAIC model,

\section{Modified Value Added Intellectual Coefficient (M-VAIC)}

M-VAIC model (Ulum, 2014) begins by assessing the company's ability to create value-added (VA) which is the efficiency of human capital (HC), structural capital (SC), relational capital (RC), and capital employed (CE). Following Pulic research (2004), VA can be calculated by the total of Operating Profit (OP), Employee Cost (EC), Depreciation (D) and Amortization (A). The process of value creation efficiency (VA) is influenced by the efficiency of four components, which will be added together to form M-VAIC indicator which are:

1. Human Capital Efficiency (HCE). HCE shows how much VA can be generated with the cost for labor whereas HC's proxy are salaries and employee benefits.

2. Structural Capital Efficiency (SCE). SCE shows the contribution of structural capital (SC) in value creation. SCE measures the amount of SC needed to produce 1 rupiah of $\mathrm{VA}$. The greater the input of $\mathrm{HC}$ in value creation, the less the input of SC, where SC is VA minus HC. HCE, SCE, and RCE together will result in Intellectual Capital Efficiency (ICE).

3. Relational Capital Efficiency (RCE). RCE is an additional component to calculate the performance of intellectual capital that proposed by Ulum (2014) in his research. RCE measures the amount of RC needed to produce 1 Rupiah of VA. In his research, Ulum (2014) uses the company's marketing costs as an indicator of the RC.

4. Capital Employed Efficiency(CEE). CEE shows the contribution made by each unit of CE to VA. According to Pulic (2000; 2004), if one unit of CE generates a larger return than other company in the same sector, it means that the company can use their CE more efficiently.

\section{Company Financial Performance}

Company financial performance is the measure of a company's financial condition during a particular period. Performance can be a benchmark for company's ability to manage and allocate all of their available resources to obtained profit from their operating activities. 
The ratio that used to measure the financial performance is the return on assets (ROA). Based on an assessment letter from Bank Indonesia (BI) No. 23/67/KEP/DIR in 1991, the minimum limit for ROA in banking sector is $1 \%$.

\section{Firm Value}

Firm Value is reflected in the stock price. A company that has a great value will be a hot item among investors. The company's value in this study was measured using PBV (Sudibya, 2014). PBV describes the given market premium on the intellectual capital of the company. High PBV means that company has a stock price that greater than the book value per share. The company that has high stock price reflected their ability to create value for shareholders. The company that can successfully create a value will certainly give hope to the shareholders in the form of greater profits (Agus Sartono, 2001 in Sudibya, 2014).

\section{Hypotheses Development}

Company investment in the form of intellectual capital will have an impact on the difference between market value and book value. RBT supports the statement an intellectual capital that well managed will have an impact on the increase in firm value.

According to stakeholder theory, all of the company's activities begin from value creation. Stakeholders can appreciate a company that has superior intellectual capital because it will help the company to fulfill all of the stakeholders interests. Investors as one of the stakeholders in the capital market will show their appreciation by invest in the company. Researches done by Randa (2012) and Berzkalne (2014) proves that intellectual capital has a positive effect on firm value. Based on this, the first hypothesis is:

H1: Intellectual capital has a positive effect on firm value.

A company in RBT, described as a collection of tangible and intangible assets and a financial performance is the effectiveness of the tangible and intangible assets utilizitation (Firer and Williams 2003 in Sunarsih, 2012).

Stakeholder theory states that the companh which have a high intellectual capital will be capable of generating value added, and makes the company have better performance than before. This high performance will increase the stakeholders' trust to the company. The study done by Chen et al. (2005), Ulum et al. (2008), and Clarke et al. (2011) proves that intellectual capital has a positive influence on the company financial performance, then the second hypothesis proposed in this study is:

$\mathrm{H} 2$ : Intellectual capital has a positive effect on financial performance.

An efficient utilization of tangible and intangible assets in a company according to RBT theory would provide a competitive advantage for the company, thus increasing the productivity and the value of the company. Stakeholder theory states that a good financial performance will have an impact on increasing the confidence of shareholders. Shareholders trust in a company reflected on how they assess the company in the capital market. 
Research conducted by Sunarsih (2012), Alghifari et al. (2013) and Sudibya (2014) proved the existence of a positive relationship between financial performance and firm value. Based on this, the third research hypothesis proposed in the study are:

H3: Financial Performance has a positive effect on firm value.

According to the RBT theory, a company can compete competitively if the company can manage and use their resources efficiently. It can only be done if it's supported by a good intellectual ability. When resources are managed effectively and efficiently, it can lead to value added and have an impact on the competitive advantages that exist in the company.

According to stakeholder theory, a company needs to perform an action to increase their value so stakeholders can have a high trust in the company. The increase in the value of these companies can be done with the effective utilization of the company's intellectual capital.

Belkaoui in Sunarsih (2012) states that the company's investment in intellectual capital presented in the financial statements, was the result from the increased between the differences of market value and book value. Intellectual capital is a measurable resource for the increased of competitive advantages. Hence intellectual capital will give a contribution to the financial performance and firm value (Chen et al., 2005).

Researches done by Sunarsih (2012) and Muna (2014) proves that intellectual capital has an indirect effect on the value of the company through financial performance as an intervening variable. Based on this statement, the fourth hypothesis in this study are:

H4: Intellectual capital has an indirect effect on the firm value through financial performance.

\section{RESEARCH METHODOLOGY \\ Independent variable}

The independent variable in this study is the intellectual capital measured by the efficiency of intellectual capital in the creation of value added using VAICTM measurements that have been modified (M-VAIC) by Ulum (2014). M-VAIC calculation results are categorized into four categories:

1) Top performers - M-VAIC value above 3.50

2) Good performers - M-VAIC value between 2.5 and 3.49

3) Common performers - M-VAIC value between 1.5 and 2.49

4) Bad performers - M-VAIC value below 1.5.

Company that fall into Top Performers category indicated as a company that can manage and exploit their intellectual capital very efficiently in order to create value added. Meanwhile, the companies that fall into lowest category, which is Bad Performers indicated as a company that can not take advantage of their intellectual capital efficiently to create value added. 
The formula to calculate M-VAIC is as follows (Ulum, 2014):

\section{M-VAIC = HCE + SCE + RCE + CEE}

Information:

HCE : Human Capital Efficiency $=$ VA $/ \mathrm{HC}$

VA : Value Added $=\mathrm{OP}+\mathrm{EC}+\mathrm{D}+\mathrm{A}$

OP : Operating Profit

EC : Employed Cost

D : Depreziation

A : Amortization

HC : Human Capital, in the form of wages and salaries

SCE : Structural Capital Efficiency $=\mathrm{SC} / \mathrm{VA}$

SC : Structural Capital = VA-HC

RCE : Relational Capital Efficiency $=\mathrm{RC} / \mathrm{VA}$

RC : Relational Capital, in the form of marketing costs

CEE : Capital Employed Efficiency = VA $/$ CE

CE : Capital Employed available for funds (equity)

\section{Dependent variable}

The dependent variable in this study is the firm value that measured using the Price to Book Value (PBV). PBV can show how the company creates value for the company. Company that well managed generally have PBV above 1, which shows the market value is higher than its book value. PBV is calculated using this formula:

$$
P / B \text { Ratio }=\frac{\text { Market Price per Share }}{\text { Book Value per Share }}
$$

\section{Intervening variable}

Intervening variable in this research is financial performance which measured using Return on assets (ROA). ROA ratio in this study was formulated as follows:

$$
R O A=\frac{N e t \text { Income }}{\text { Average Total Assets }}
$$

The sample is 15 companies from banking sector listed in Indonesia Stock Exchange in 2011-2014, that has met the requirements which are the sample report all of their financing aspect on audited financial statements and don't have negative equity book value and profit during the observation period. Data analysis using path analysis with this formula:

$$
\mathrm{PBV}=\alpha+\beta 1+\beta 3 \mathrm{MVAIC} \mathrm{ROA}+\varepsilon
$$

$\mathrm{ROA}=\alpha+\beta 2 \mathrm{MVAIC}+\varepsilon$

Information:

$$
\begin{array}{ll}
\text { PBV } & =\text { Firm value } \\
\text { M-VAIC } & =\text { Modified Value added intellectual coefficients company } \\
\text { ROA } & =\text { Financial Performance } \\
\alpha & =\text { Constant } \\
\beta 1 & =\text { The coefficients of PBV on M-VAIC } \\
\beta 2 & =\text { The coefficients of ROA on M-VAIC } \\
\beta 3 & =\text { The coefficients of ROA on PBV }
\end{array}
$$


$\varepsilon \quad=$ Residual

\section{RESULTS}

Table 1 Descriptive Statistics

\begin{tabular}{lccccc}
\hline & N & Minimum & Maximum & Mean & Std. deviation \\
\hline MVAIC & 60 & 1.83 & 6.36 & 3.5921 & 1.09841 \\
ROA & 60 & .0022 & .03 & .0163 & 0.00793 \\
PBV & 60 & .296 & 4.86 & 1.7308 & 1.13533 \\
Valid N (listwise) & 60 & & & &
\end{tabular}

Table 1 showed that the average value of M-VAIC is above 3.5. Therefore, companies that become samples in this research fall into the top performers category (Ulum, 2014). Top performer means that the company can utilize their intellectual capital efficiently.

ROA value of samples averagely is greater than the minimum ROA limit set by Bank Indonesia which is $1 \%$. PBV value of samples averagely is above 1 , indicated that samples market value is greater than their book value.

\section{Hypothesis Testing}

Table 2 Results 1

\begin{tabular}{lcccc}
\hline \multicolumn{1}{c}{ Variable } & Sign & Koef. & T & Sig. \\
\hline MVAIC & $(+)$ & .447 & 2.624 & .011 \\
\hline R Square & & .108 & & \\
Adj R Square & & .092 & & \\
F & 6.883 & & \\
Sig & .011 & & \\
\hline Dependent Variable: SQRTPBV_1
\end{tabular}

Table 2 shows the $\beta 1$ coefficient (.447) is significant at $5 \%(.011)$. This proves that there is a direct positive effect of intellectual capital (M-VAIC) on firm value (PBV), which meant that any increase in the efficiency of utilization of intellectual capital will increase the company's value.

Table 3 Results 2

\begin{tabular}{lcccc}
\hline \multicolumn{1}{c}{ Variable } & Sign & Koef. & T & Sig. \\
\hline MVAIC & $(+)$ & .078 & 7.269 & .000 \\
\hline R Square & & .481 & & \\
Adj R Square & & .472 & & \\
F & 52.832 & & \\
Sig & .000 & & \\
\hline Dependent Variable: SQRTROA_1 & &
\end{tabular}

Based on table 3 , the $\beta 2$ coefficient (.04) is significance at $5 \%$ (.000). This shows that there is a positive effect of intellectual capital (M-VAIC) on financial performance (ROA), which means that any increase in the efficiency of utilization of intellectual capital will improve financial performance. 
Table 43 Hypothesis Testing Results

\begin{tabular}{lcccc}
\hline \multicolumn{1}{c}{ Variable } & Sign & Koef. & T & Sig. \\
\hline ROA & $(+)$ & 6.204 & 4.510 & .000 \\
\hline R Square & & .263 & & \\
Adj R Square & .250 & & \\
F & 20.341 & & \\
Sig & .000 & & \\
\hline Dependent Variable: SQRTPBV_1
\end{tabular}

Table 4 shows the $\beta 3$ coefficient (6.204) is significance at $5 \%$ (.000). This indicates that there is a positive effect of financial performance (ROA) to firm value (PBV), which means that any increase in the company's financial performance would enhance its value.

Table 5 Effect of Direct and Indirect Influence

\begin{tabular}{ccccc}
\hline \multirow{2}{*}{ VARIABLE } & \multicolumn{2}{c}{ M-VAIC } & \multicolumn{2}{c}{ ROA } \\
\cline { 2 - 5 } & PL & PTL & PL & PTL \\
\hline ROA & $.078(\beta 2)$ & - & - & - \\
PBV & $.447(\mathrm{~B} 1)$ & .484 & $6.204(\mathrm{~B} 3)$ & - \\
\hline
\end{tabular}

Table 5 shows the direct influence (DI) of intellectual capital (M-VAIC) on financial performance (ROA) is .078. The DI of intellectual capital (M-VAIC) to firm value (PBV) is .447 and the DI of financial performance (ROA) to firm value (PBV) is 6.204. The effect of intellectual capital (M-VAIC) to firm value (PBV) through financial performance (ROA) is 0.484 (0.078 x 6.204).

The result indicates that intellectual capital has the capability to affect firm value directly or indirectly through financial performance. The indirect effect that has higher value than direct effect means that intellectual capital will have a better ability to improve firm value if IC affect FV through financial performance.

This is the sensitivity test results to see which of the Intellectual Capital constructs are the most influential to firm value and financial performance:

Table 6 Sensitivity Test Intellectual Capital Constructs on Firm Value

\begin{tabular}{cccc}
\hline Variable & Koef. & $\mathbf{t}$ & Sig. \\
\hline HCE & 2.088 & 3.879 & .000 \\
SCE & -5.412 & -3.267 & .002 \\
RCE & 0.764 & .994 & .324 \\
CEE & 3.507 & 5.048 & .000 \\
\hline
\end{tabular}

Dependent Variable: SQRTPBV_1

Table 6 shows that CEE (3.507) have the most significant effect at the level of $5 \%$ to the firm value followed by HCE (2.088). RCE is positive at .764 , but the effect is not significant. SCE negatively impacts the firm value at -5.412 . From these results, it is known that the increases in HCE, RCE, and CEE, will increase the firm value. But if there is an increase in SCE, it will reduce the firm value. 
Table 7 Sensitivity Test Intellectual Capital Construct on Financial Performance

\begin{tabular}{cccc}
\hline Variable & Koef. & t & Sig. \\
\hline HCE & .008 & .341 & .735 \\
SCE & .232 & 3.113 & .003 \\
RCE & -.064 & -1.849 & .070 \\
CEE & .230 & 7.355 & .000 \\
\hline
\end{tabular}

Dependent Variable: SQRTROA_1

Table 7 shows that SCE has the greatest influence on ROA with a coefficient of .232 followed by CEE with a coefficient of .230. HCE has a coefficient of .008, but not significant at 5\%. RCE has a negative coefficient of -.064 and is not significant at 5\%. This indicates that each of the increase in HCE, SCE, and CEE, will increase the company's financial performance meanwhile it will be reduced if RCE value increased.

\section{DISCUSSION}

\section{Intellectual Capital and Firm Values}

The first results indicate that there is a positive effect of intellectual capital on firm value. Every time the efficiency of intellectual capital increased, the firm value will also be increased. It means that the market has given a high appraisal to the banking sector that can utilize their intangible assets especially intellectual capital for value added creation.

Statistically, banking sector on average falls into Top Performers category, and this is one of the reasons why the market gave high appraisal for Indonesian banking sector. These results differ from Sunarsih's research (2012) where the research sample has an average value of 1.51. The low value is one of the reasons why no direct influence found on intellectual capital to firm value because low IC value made the market wouldn't give a high assessment to the company.

The banking sector in its operating activities relies heavily on the intellectual abilities of human resources as well as its technology. High intellectual capital value shows that the banking sector has proven to utilize their intangible resources, especially intellectual capital efficiently so that in the end the company's value in the market can be increased.

This finding is consistent with RBT theory which states that the intangible resources which can be managed efficiently, especially the intellectual capital, can help companies to achieve a competitive advantage, so it will attract investors to invest and have an impact on the increased value of the company. The stakeholder theory states that a company that can harness their intellectual capital in the creation of value added efficiently will help the company to meet the interests of stakeholders, especially investors so that they will show their appreciation by investing in the company.

The results of this study are consistent with Randa (2012), Berzkalne (2012), and Sudibya (2012), but the study was not consistent with the research by Sunarsih 
(2012) in which there's no direct influence on the value of the intellectual capital of the company.

\section{Intellectual Capital and Financial Performance}

The second test results indicate that intellectual capital has a positive effect on financial performance, which means that the higher the utilization of intellectual capital in the creation of value added, will increase the effect of company's efforts to get a better financial performance. By leveraging the intellectual capital they have, the company's financial performance can be increased through increased revenue without adding the costs and expenses. The findings of this study also indicate that the more efficient the companies can manage their intellectual capital (human capital, structural capital, relational capital and capital employed), the more their financial performance will improve.

The average value of the samples financial performance has been above the minimum level set by the central bank. It means that the financial performance value is directly proportional to the intellectual capital value. The average value is proven that the ownership of high intellectual capital would have an impact on their financial performance which can occur with an increase in revenues generated by their intangible assets without adding their costs and expenditures.

The second hypothesis proves that an increase in intellectual capital will also increase banking company assets for their operating activities that focused on the intellectual abilities of their employees, technology which they owned and how banking sector can persuade a customer to make a loan or opened a bank account. Thus, an increase in intellectual capital can also be accompanied by an increase in revenue. Therefore, the ROA ratio will be increased if the IC increase too.

These findings support the RBT theory that the company's performance is a result of tangible and intangible assets owned by the company, in this case, is the intellectual capital. Excellent management of intellectual capital will help the company to achieve a competitive advantage thus improving their financial performance. These findings also support the stakeholder theory, which states that a company that can utilize their intellectual capital efficiently to create value-added will improve their financial performance. The high value of performance will increase stakeholders trust to the company, especially the shareholders or investors.

The results of this study are consistent with findings Ulum (2008), Chen et al. (2005), Clarke et al. (2011), Sunarsih (2012) and Sudibya (2014) which states that intellectual capital is a positive influence on the financial performance of the company.

\section{Financial Performance and Value}

The third test result shows that financial performance has a positive effect on firm value. It means that financial performance is directly proportional to their firm value. The average market value of the banking company has been above its book value shows that on average the banking company has been rated highly by the market. Financial performance (ROA) were proven to have a positive effect on firm value (PBV), indicates that the value of ROA is one of the factors that determines how much the PBV owned by banking company. High ROA value shows the high 
level of profit achieved by the and demonstrates the ability of a good asset management.

This test is consistent with the RBT theory which states that the effective and efficient utilization of tangible and intangible assets will enhance the company's ability to generate more operating profit. It would result in the increase of return received by shareholders and ultimately increase the firm value in the capital market.

This finding is also consistent with stakeholders theory which shows that high financial performance of the company will attract investors to invest in the company (Arifin in Sudibya, 2014). It would also have an impact on the stock price in the market and will end in an increase of firm value.

The results of this study are consistent with studies that have been done before, namely from Sunarsih (2012), Alghifari et al. (2013), and Sudibya (2014). These studies state that financial performance has a positive influence on the value of the company.

\section{Intellectual Capital, Financial Performance and Value}

Research shows that financial performance intervenes the relationship between intellectual capital and firm value of the company with higher value if through financial performance. From these results, it can be concluded that the companies were able to manage their intellectual capital as good as they can to create value added and competitive advantage through innovation, research, and development, which will lead to an increase in the company's financial performance. The better financial performance will attract the attention of investors to invest so that the company's market value will increase.

Intellectual capital is influenced by four constructs which are HCE, SCE, RCE, and CEE. High intellectual capital value shows that that banking sector has employees who are competent, creative, able to work efficiently and would not incur costs that are not needed. Then it is also indicated that the facilities and infrastructure owned by banks, such as databases, software, and organizational structure could support the entire employee to increase bank's performance and can provide value added to attract the investors. Also, banking sector already has a good marketing system and promotion for introducing the bank to the public so that it can attract more customers. Banks that have sufficient funds can meet investors' expectations because the funds can be used for the payment of dividends to investors.

This results support RBT theory that if the resources were managed effectively and efficiently, it would create value added for the company. An increase in value added will increase financial performance and will result in competitive advantages for the company. A company that has a competitive advantage will attract more investors, which in turn will increase the company's value in the capital market. This finding is also consistent with the stakeholders theory, which states that company would use their intellectual capital to increase the firm value. The better utilization of intellectual capital will reflect on how high company's financial performance can generate more profits. Companies that can 
efficiently use their resources to produce a high return for shareholders will increase their firm value.

The result is consistent with the results of research done by Sunarsih (2012) and Muna (2012) where they found an indirect effect of intellectual capital on firm value via financial performance.

\section{CONCLUSION}

\section{Conclusion}

From the first hypothesis result, we know that the market will give a company a high appraisal if it's capable of utilizing its intellectual capital to create valueadded. From the second hypothesis, we can conclude that the efficient use of intellectual capital is proven to improve the company's financial performance in the banking sector by increasing its revenues without adding to the expense and costs. The third hypothesis result indicated that the increase in a company's financial performance, will attract more investors to invest, thus will give the company higher value in the capital market. The fourth hypothesis result shows that a company that can manage their intellectual capital properly will create a value added and thus from there, it will also create a competitive advantage and result in increased financial performance. A better financial performance will attract the attention of investors to invest in the company. Thus it will increase its value in the capital market.

\section{Research limitations}

1. This study was done only to banking sector companies that listed in BEI between 2011-2014.

2. Adj R Square value of the independent variable are still relatively small at under 50\%. Even Adj R Square value of intellectual capital on firm value is only $9 \%$. It indicates that there are other independent variables that affect the firm value.

\section{Suggestion}

1. Companies from other sectors should be added or the period of the study should be extended.

2. Using alternative indicators or models other than M-VAIC model to measure intellectual capital.

3. Indicator for Financial performance can use Employee Productivity (EP), Return on Equity (ROE) or Growth Revenue (GR) just like in the researches by Chen et al. (2005) and Clarke et al. (2011). The firm value can use Tobin's Q as in the researches by Randa (2012), Al Ghifari (2013) and Berzkalne (2014).

\section{References}

Alghifari, S., Triharjono, S., \& Juhaeni, Y. (2013). Effect of Return on Assets (ROA) Against Tobin's Q: Studies in Food and Beverage Company in Indonesia Stock Exchange Years 2007-2011. International Journal of Science and Research (IJSR), 2, 108-116. 
Barney, J. (1991). Firm Resources and Sustained Competitive Advantage. Journal of Management, 17(1), 99-120.

Berzkalne, I., \& Zelgalve, S. (2013). Intellectual Capital and Company Value. Contemporary Issues in Business, Management and Education. [Dissertation]. Latvia: University of Latvia.

Chen, M.C., S.J. Cheng., \& Y. Hwang. (2005). An Empirical Investigation of the Relationship Between Intellectual Capital and firms' Market Value and Financial Performances. Journal of Intellectual Capital, 6(2), 159-176.

Clarke, Martin., Seng, D., \& Rosalind H. W. (2011). Intellectual Capital and Firm Performance in Australia. Journal of Intellectual Capital, 12(4), 505 - 530.

Deegan, C. (2004). Financial Accounting Theory. McGraw-Hill Book Company. Sydney.

Freeman, R.E., \& Reed. (1983). Stockholders and Stakeholders: A New Perspective on Corporate Governance. Californian Management Review, 25(2), 88-106.

Hong, P., Tan, D. P., \& Hancock, P. (2007). Intellectual Capital and Financial Return of Companies. Journal of Intellectual Capital, 3(1), 51-61.

Ikatan Akuntan Indonesia. (2015). Standar Akuntansi Keuangan: Pernyataan Standar Akuntansi Keuangan, No. 19. Jakarta: Salemba Empat.

Kamath, G.B. (2007). The Intellectual Capital Performance of Indian Banking Sector. Journal of Intellectual Capital, 8(1), 96-123.

Muna, N. (2014). Pengaruh Intellectual Capital Terhadap Retun Saham Melalui Kinerja Keuangan Pada Perusahaan Real Estate dan Properti yang Terdaftar di Bursa Efek Indonesia (BEI) Tahun 2010-2012. [Theses]. Indonesia: Universitas Diponegoro Semarang.

Penrose, R.T. (1959). The Theory of The Growth of The Firm. Basil Blackwell \& Mott Ltd. Great Britaino.

Pulic, A. (2000). VAICTM- an Accounting Tool For Intellectual Capital Management. International Journal of Technology Management, 20(5-8), $702-722$.

. (2004). Intellectual Capital-Does It Create Or Destroy Value. Measuring Business Excellence, 8(1), 62-68.

Randa, F., \& Solon, S. A., (2012). Pengaruh Modal Intelektual Terhadap Nilai Perusahaan (Studi Empiris pada Perusahaan Manufaktur yang Terdaftar di Bursa Efek Indonesia). Jurnal Sistem Informasi Manajemen dan Akuntansi, 10(1), 24-47.

Sudibya, D. C. N. A., \& Restuti, M. M. D. (2014). Pengaruh Modal Intelektual Terhadap Nilai Perusahaan Dengan Kinerja Keuangan Sebagai Variabel Intervening. Seminar Nasional dan Call for Paper (Sancall 2014) : Research Methods and Organizational Studies, 154-166.

Sawarjuwono, T., \& Kadir, A. P. (2003). Intellectual Capital: Perlakuan, Pengukuran dan Pelaporan (Sebuah Library Research). Jurnal Akuntansi dan Keuangan, 5(1), 31-51.

Selznick, P. (1957). Leadership in Administration: A Sociological Interpretation. Evanston, Illinois: Row, Peterson and Company.

Stewart, T. A. (1991). Brainpower: How Intellectual Capital is Becoming America's Most Valuable Asset. Fortune, (June), 44-60.

Sunarsih, N. M., \& Mendra, N. P. Y. (2012). Pengaruh Modal Intelektual Terhadap Nilai Perusahaan dengan Kinerja Keuangan Sebagai Variabel Intervening 
Pada Perusahaan yang Terdaftar di Bursa Efek Indonesia. Simposium Nasional Akuntansi XV. Banjarmasin.

Ulum, I. (2007). Pengaruh Intellectual Capital Terhadap Kinerja Keuangan Perusahaan Perbankan di Indonesia. Thesis pada Universitas Diponegoro Semarang - Indonesia.

. (2008). Intellectual Capital dan Kinerja Keuangan Perusahaan: Suatu Analisis Dengan Pendekatan Partial Least Squares. SNA XI Pontianak. (2013). Intellectual Capital corner | Resource-Based Theory (RBT). [Online]. Tersedia: http://ihyaul.staff.umm.ac.id/2013/05/resource-basedtheory-rbt/ [23 Januari 2015]

. (2014). Intellectual Capital Performance of Indonesian Banking Sector: A Modified VAIC (M-VAIC) Perspective. Asian Journal of Finance and Accounting, 6(2), 103-123.

Watts, R.L., \& Zimmerman, J.L. (1986). Positive Accounting Theory. PrenticeHall. Englewood Cliffs. NJ.

Wernerfelt, B. (1984). A Resource-Based View of The Firm. Strategic Management Journal, [e-journal] 5(2).

http://www.bi.go.id

http://www.dunamis.com

http://finance.yahoo.com

http://idx.co.id 